\title{
Chemical Looping Combustion with Different Types of Liquid Fuels
}

\author{
A. Hoteit, A. Forret, W. Pelletant, J. Roesler and T. Gauthier* \\ IFP Energies nouvelles-Lyon, Rond-point de l'échangeur de Solaize, BP 3, 69360 Solaize - France \\ e-mail: ali.hoteił@ifpen.fr - ann.forret@ifpen.fr - william.pelletant@ifpen.fr - john.roesler@ifpen.fr - thierry.gauthier@ifpen.fr \\ * Corresponding author
}

\begin{abstract}
Résumé - Combustion en boucle chimique avec différentes charges liquides - Le CLC est un nouveau concept prometteur appliqué à la combustion qui permet le captage de $\mathrm{CO}$ en minimisant la pénalité énergétique liée au captage. Jusqu'à présent, l'essentiel des travaux de recherche dans le domaine du CLC concerne les charges gazeuses (méthane) et solides (charbon et coke). Les charges liquides, et particulièrement les résidus pétroliers, sont des charges également intéressantes à considérer a priori. La mise en œuvre de ces charges en lit fluidisé est cependant délicate. L'objet de ce travail est d'étudier la faisabilité de la combustion partielle ou totale des charges liquides dans les conditions du CLC au contact d'un matériau porteur d'oxygène.

Un petit réacteur en lit fluidisé opérant en batch a été développé pour permettre alternativement le contact du matériau porteur d'oxygène avec une charge liquide ou de l'air. Le réacteur de $20 \mathrm{~mm}$ de diamètre est rempli de $45 \mathrm{~g}$ de particules de $\mathrm{NiAl}_{0.44} \mathrm{O}_{1.67}$. Environ 1-2 $\mathrm{g}$ de charge liquide est injecté par pulse dans le lit à des températures allant jusqu'à $950^{\circ} \mathrm{C}$. Différentes charges liquides ont été étudiées, du dodécane au fioul lourd n ${ }^{\circ} 2$. Les résultats montrent que pendant la période de réduction du matériau porteur d'oxygène, il est possible de convertir tous les hydrocarbures injectés. À l'issue de cette phase, il ne subsiste pas de dépôt de coke à la surface des particules. En fonction de la quantité d'oxygène disponible dans le lit, on effectue une combustion totale ou partielle des hydrocarbures injectés. Des résultats similaires sont obtenus pour les différents hydrocarbures testés, malgré leurs propriétés $a$ priori très différentes.
\end{abstract}

\begin{abstract}
Chemical Looping Combustion with Different Types of Liquid Fuels - CLC is a new promising combustion process for $\mathrm{CO}_{2}$ capture with less or even no energy penalty compared to other processes. Up to now, most of the work performed on CLC was conducted with gaseous or solid fuels, using methane and coal and/or pet coke. Liquid fuels such as heavy fuels resulting from oil distillation or conversion may also be interesting feedstocks to consider. However, liquid fuels are challenging feedstock to deal with in fluidized beds. The objective of the present work is therefore to investigate the feasibility of liquid feed injection and contact with oxygen carrier in CLC conditions in order to conduct partial or complete combustion of hydrocarbons.

A batch experimental fluidized bed set-up was developed to contact alternatively oxygen carrier with liquid fuels or air. The $20 \mathrm{~mm}$ i.d. fluidized bed reactor was filled up with $45 \mathrm{~g}$ of $\mathrm{NiAl}_{0.44} \mathrm{O}_{1.67}$ and pulses of $1-2 \mathrm{~g}$ of liquid were injected in the bed at high temperatures up to $950^{\circ} \mathrm{C}$. Different feedstocks have been injected, from dodecane to heavy fuel oils No.2. Results show that, during the reduction period, it is possible to convert all the fuel injected and there is no coke remaining on particles at the end of the reduction step. Depending upon oxygen available in the bed, either full combustion or partial combustion can be achieved. Similar results were found with different liquid feeds, despite their different composition and properties.
\end{abstract}




\section{INTRODUCTION}

Over the last 10-15 years, chemical looping routes have started to be investigated in order to provide clean and efficient solutions for several applications such as combustion and hydrogen production. CLC is one of the promising route for $\mathrm{CO}_{2}$ capture since no specific separation of $\mathrm{O}_{2}$ from air nor $\mathrm{CO}_{2}$ from flue gas is required, resulting in expected much lower energy penalties. The chemical looping concept is based on the use of Oxygen Carriers (OC) materials with oxidation-reduction cycles that can either oxidize or reduce feedstocks. Chemical Looping Combustion (CLC) is a flameless combustion technology where there is no direct contact between air and fuel. In combustion, $\mathrm{CO}_{2}$ rich effluents can be directly produced, enabling subsequent $\mathrm{CO}_{2}$ transportation and storage. Theoretical analyses of the technology indicate that its use results in increased power efficiency compared to regular combustion [1].

This combustion process is divided into two steps (see Fig. 1): reduction and oxidation. In the reduction step, fuel is oxidized by reduction with a metal oxide via the following reactions:

$$
\begin{gathered}
(2 n+m) \mathrm{Me}_{x} \mathrm{O}_{y}+\mathrm{C}_{n} \mathrm{H}_{2 m} \rightarrow(2 n+m) \mathrm{Me}_{x} \mathrm{O}_{y-1}+m \mathrm{H}_{2} \mathrm{O}+n \mathrm{CO}_{2} \\
\mathrm{Me}_{x} \mathrm{O}_{y}+\mathrm{CO} \rightarrow \mathrm{Me}_{x} \mathrm{O}_{y-1}+\mathrm{CO}_{2} \\
\mathrm{Me}_{x} \mathrm{O}_{y}+\mathrm{H}_{2} \rightarrow \mathrm{Me}_{x} \mathrm{O}_{y-1}+\mathrm{H}_{2} \mathrm{O}
\end{gathered}
$$

(where $\mathrm{Me}_{x} \mathrm{O}_{y}$ is the metal oxide, and $\mathrm{Me}_{x} \mathrm{O}_{y-1}$ is the reduced metal oxide).

In the oxidation step, the reduced metal oxide is reoxidized by contact with air via the following reaction:

$$
\mathrm{Me}_{x} \mathrm{O}_{y-1}+{ }^{1 / 2} \mathrm{O}_{2} \rightarrow \mathrm{Me}_{x} \mathrm{O}_{y}
$$

The net result of these two steps is the direct combustion of the fuel gases with oxygen:

$$
\begin{gathered}
\mathrm{C}_{n} \mathrm{H}_{2 m}+{ }^{1 / 2}(2 n+m) \mathrm{O}_{2} \rightarrow n \mathrm{CO}_{2}+m \mathrm{H}_{2} \mathrm{O} \\
\mathrm{CO}+{ }^{1 / 2} \mathrm{O}_{2} \rightarrow \mathrm{CO}_{2} \\
\mathrm{H}_{2}+{ }^{1 / 2} \mathrm{O}_{2} \rightarrow \mathrm{H}_{2} \mathrm{O}
\end{gathered}
$$

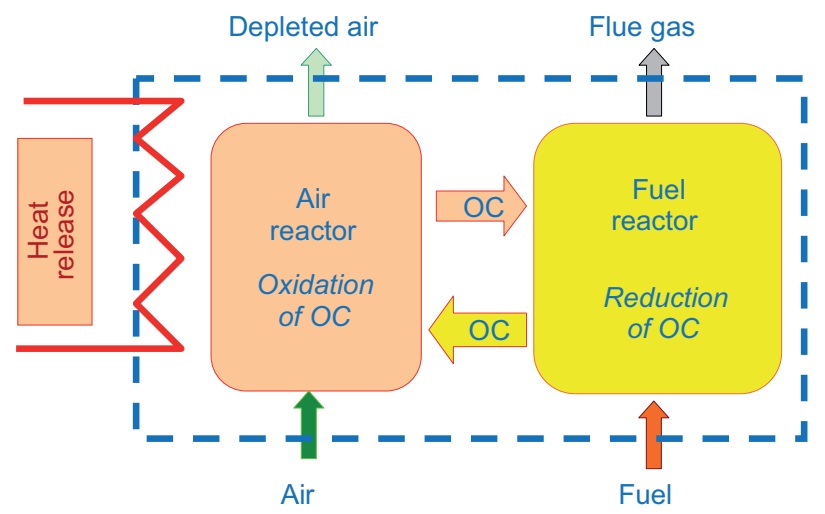

Figure 1

Principle of Chemical Looping Combustion.
Most of the power plants in the world today burn coal and gas. However, power plants using liquid fuels such as heavy fuel oils still represent a significant portion of the market in the range of $10-15 \%$ worldwide. Furthermore, based on the increasing production of very heavy oils and oils sands, very heavy unconverted hydrocarbon liquid feedstocks may be available in the future for energy production.

Up to now, most of the researches in Chemical Looping Combustion have focused on the use of gaseous fuels [2-3] or solid fuels [4-7]. It was found that CLC combustion with solid fuels is more challenging than CLC reactions with gas fuels. Indeed, with solid fuels, reaction mechanisms are resulting first, from a gasification step and then, from combustion of the syngas produced in the first step. The gasification step is rather slow compared to syngas combustion and, most likely, remains the limiting step [8].

There are a lot of challenges to face when considering the combustion of liquid fuels. Some of the difficulties may be related to the fuel injection at high temperature in the fluidized bed. Coke may also deposit on the OC materials, which may limit the oxygen release from the material. Furthermore, it may be difficult to separate coked OC materials from non coked OC materials when returning particles from the fuel reactor to the air reactor. However, up to now, there is no detailed experimental work reported in the literature concerning CLC with liquid fuels.

\section{OBJECTIVES}

Liquid fuels such as heavy fuels resulting from oil distillation or conversion may be interesting feedstocks to consider for CLC applications. Liquid fuels are challenging feedstock to deal with in fluidized beds. The objective of the present work is therefore to investigate the feasibility of liquid feed injection and contact with oxygen carrier in CLC conditions in order to conduct partial or complete combustion of hydrocarbons.

A new reactor has been developed for the present study; it was implemented in a batch pilot plant system enabling sequential liquid injection in order to conduct Chemical Looping Combustion. Results have already been reported with the dodecane liquid fuel that was used as a model compound to start up the unit [9]. In the present study, the objective was, additionally, to study feed effects, by comparing results obtained with $n$-dodecane, domestic fuel oil and heavy fuel oil.

\section{EXPERIMENTAL}

\subsection{Oxygen-Carrier Materials}

The oxygen carrier used in the present study is $\mathrm{NiO} / \mathrm{NiAl}_{2} \mathrm{O}_{4}$ which consisted of $60 \mathrm{wt} \%$ active phase and $40 \%$ support 
material. This Ni-based OC material was manufactured by Marion Technologies (France). Its average arithmetic and harmonic diameters are 171 and $125 \mu \mathrm{m}$, respectively. The bulk density of the particles is $2200 \mathrm{~kg} / \mathrm{m}^{3}$. The BET surface area of the particles is $7 \mathrm{~m}^{2} / \mathrm{g}$. The maximum oxygen-carrying capacity of $\mathrm{NiO} / \mathrm{NiAl}_{2} \mathrm{O}_{4}$ was measured with thermogravimatric tests; a value of $14.5 \mathrm{wt} \%$ was found, in good agreement with literature data [10]. Most of the oxygen transfer capacity is accounted for by reduction of $\mathrm{NiO}$ to $\mathrm{Ni}$ $(12.8 \%)$, and the remainder by the slower reduction of $\mathrm{NiAl}_{2} \mathrm{O}_{4}$ to $\mathrm{Ni}$ and $\mathrm{Al}_{2} \mathrm{O}_{3}$.

\subsection{Reactivity Tests in Batch Fluidized Bed Reactor}

The scheme hereafter (see Fig. 2) presents the experimental pilot plant built for the present study. It consists of a fluidized bed reactor made of quartz with $20-\mathrm{mm}$ inner diameter. The reactor can be electrically heated up to $950^{\circ} \mathrm{C}$ and is operated at atmospheric pressure. K-type chrome/alumel thermocouples are used to measure continuously temperature of the oxygen carrier bed. In standard conditions, the bed is filled up with $45 \mathrm{~g}$ of OC material that is preheated in an inert atmosphere $\left(\mathrm{N}_{2}\right)$ to the desired experimental temperature and then exposed to air to ensure that particles are fully oxidized before the reduction period.

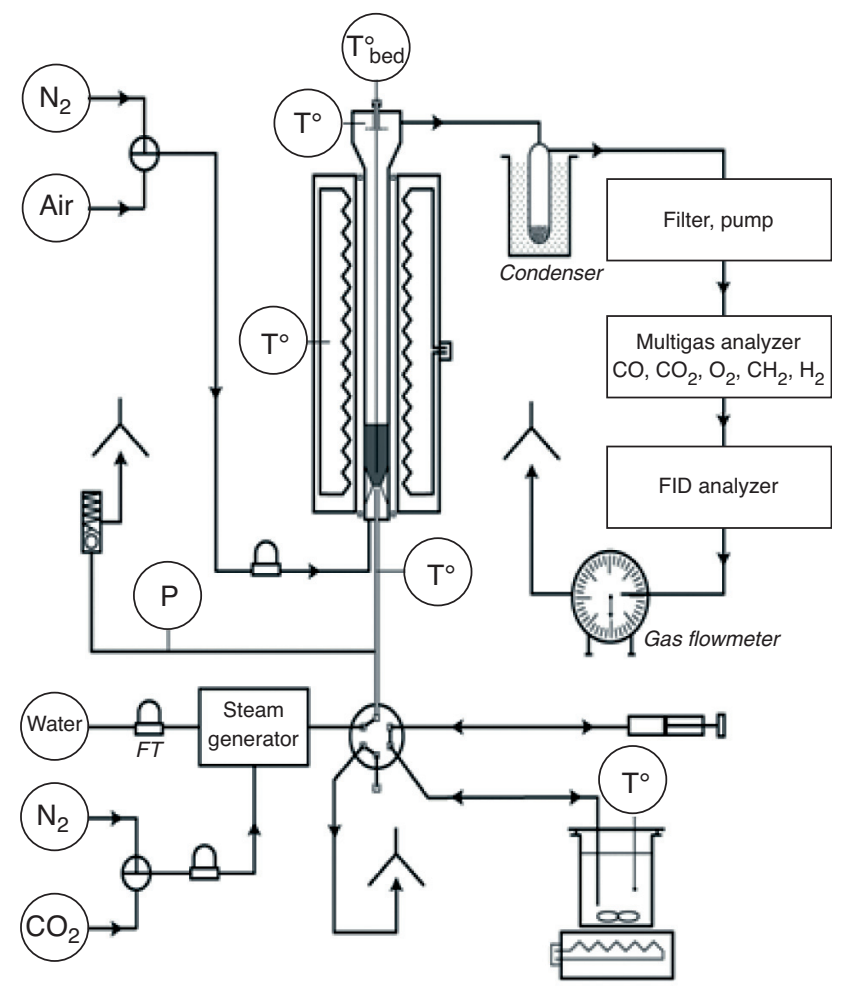

Figure 2

Experimental setup.
During the reduction step, a pulse of liquid fuel is injected at the bottom of the dense bed, via a central tube that discharges in the restriction of a convergent-divergent; the divergent representing the bottom cone of the dense bed. The flowrate of fluidization gas is $60 \mathrm{NL} / \mathrm{h}$, corresponding to about 9 times the minimum fluidization velocity.

In order to simplify the flue gas analysis process, $\mathrm{N}_{2}$ is used as the fluidization gas during the reduction step (instead of $\mathrm{CO}_{2}$ or steam). The combustion gas sample is pumped from the main flue gas line to a water condenser. The $\mathrm{H}_{2}, \mathrm{CO}$, $\mathrm{CO}_{2}, \mathrm{O}_{2}, \mathrm{HC}$ and $\mathrm{CH}_{4}$ gas concentrations are then measured. $\mathrm{CH}_{4}, \mathrm{CO}$ and $\mathrm{CO}_{2}$ are measured by Non-Dispersive Infrared Analysis (NDIR); the $\mathrm{O}_{2}$ concentration is measured in a paramagnetic analyzer and the $\mathrm{H}_{2}$ concentration by gas conductivity. Hydrocarbons are also measured by Flame Ionization Detector (FID). Data are recorded as a function of time using a data acquisition system connected to a personal computer running commercial software.

Figure 3 shows the two multi-port valve systems that were developed during the study. In a first step, the A configuration was used with $\mathrm{A} 1$ and $\mathrm{A} 2$ sequences as shown in Figure 2. However, with this system, the quantity of liquids injected in the bed with this configuration was not very accurate nor reproducible. Carbon balance during experiments ranged typically $70-75 \%$. In order to compare results obtained with different feedstocks, an improved system was developed, shown as the B configuration in Figure 3 with B1 and $\mathrm{B} 2$ sequences was used. Carbon mass balance during one experiment with this new system improved a lot and typically ranges between 90-105\% except for the heavier feedstock tested (Fuel 2, see Tab. 1) where carbon mass balance is in the range of $80-90 \%$.
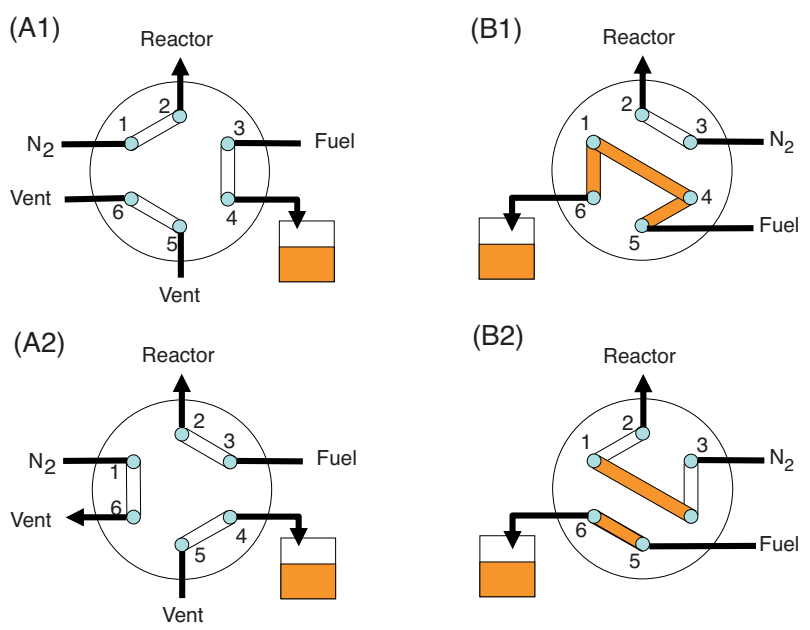

Figure 3

Multiport valve fuel injection system. 


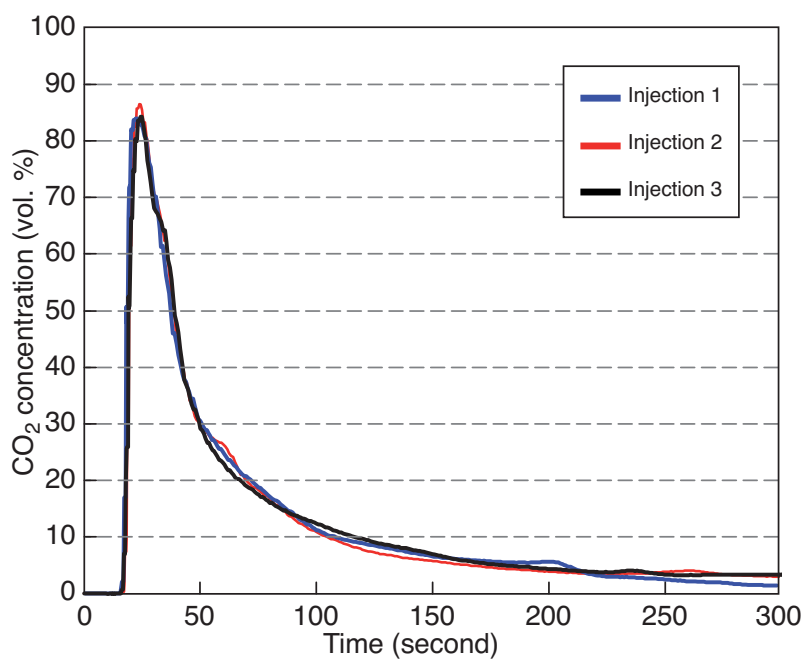

Figure 4

Reproducibility study using B configuration: dodecane mass injected $=0.618 \mathrm{~g}$; temperature $=800^{\circ} \mathrm{C}$.

Figure 4 illustrates the reproducibility of an experiment using the $\mathrm{B}$ configuration to inject the liquid feed. A dodecane injection was conducted 3 times in similar operating conditions. During these experiments, a mass of $0.614 \mathrm{~g}$ was injected in the bed at $900^{\circ} \mathrm{C}$. The $\mathrm{CO}_{2}$ concentration profile at the reactor outlet is similar from one injection to another.

To obtain a good carbon mass balance with such an experimental system remains a very difficult task. Indeed, the liquid quantities injected are small, typically one or two milliliters injected in 1-2 s. Furthermore, due to vaporization, pyrolysis, gasification and combustion reactions, the volumetric expansion of gases in the reactor is very large during the reduction. Gas flowrates and pressure change rapidly and are not easy to estimate accurately.

\subsection{Liquid Fuel Properties}

Three different liquid feedstocks were injected in the pilot unit. A pure dodecane compound was first injected. Then a domestic fuel oil (Fuel 1) and heavy fuel oil (Fuel 2) were injected in the pilot unit. Those fuels are typical commercial fuels used for power generation. The main properties of the three feedstocks are described below in Table 1 .

TABLE 1

Properties of fuels used in this study

\begin{tabular}{l|c|c|c|}
\hline & $n$-Dodecane & Fuel 1 & Fuel 2 \\
\hline Density at $15^{\circ} \mathrm{C}\left(\mathrm{kg} / \mathrm{m}^{3}\right)$ & 751 & 856 & 986 \\
\hline Carbon content $(\mathrm{wt} \%)$ & 84.7 & 87.6 & 87.9 \\
\hline Hydrogen content & 15.3 & 12.4 & 10.8 \\
\hline Sulfur content & 0 & 0.1 & 1.3 \\
\hline Nitrogen content & 0 & 0.021 & 0.46 \\
\hline
\end{tabular}

$n$-Dodecane boiling point is $216^{\circ} \mathrm{C}$. Fuel 1 is an hydrocarbon mixture with boiling points in the range of $160-360^{\circ} \mathrm{C}$. Fuel 2 is a heavier feed: more than $90 \%$ of this residue oil has a boiling point ranging above $340^{\circ} \mathrm{C}$.

\section{RESULTS}

\subsection{Dodecane Injection on $\mathrm{SiC}$}

In a first step, dodecane is injected on inert carborandum $\mathrm{SiC}$ particles at $800^{\circ} \mathrm{C}$ that replace $\mathrm{OC}$ material in order to evaluate vaporisation and thermal cracking mechanisms. During injection (with the multiport valve system A), the bed is fluidized with nitrogen; $1 \mathrm{~mL}$ of dodecane is injected during 2 seconds (at $t=1 \mathrm{~min}$ ); after 16 minutes of fluidization, nitrogen is then replaced by air to burn coke deposit on the SIC particles.

Figure 5 shows the flue gas composition during the experiment. The product stream resulting from dodecane reaction on $\mathrm{SiC}$ consists of a mixture of gases, $\mathrm{H}_{2}, \mathrm{CH}_{4}$, unreacted dodecane (Hydrocarbons) and traces of $\mathrm{CO}$. Then, during the oxidation period, after $\mathrm{O}_{2}$ introduction in the reactor, $\mathrm{CO}$ and $\mathrm{CO}_{2}$ immediately appear at the reactor outlet stream, indicating that some carbon formation occurs during reduction and remains on the $\mathrm{SiC}$ particles if no oxygen is available.

\subsection{Reduction Experiments with Dodecane}

In a second step, $\mathrm{SiC}$ material is replaced by $45 \mathrm{~g}$ of the nickel based oxygen carrier $\left(\mathrm{NiAl}_{0.44} \mathrm{O}_{1.67}\right)$ and a similar dodecane injection is conducted with multiport valve injection system

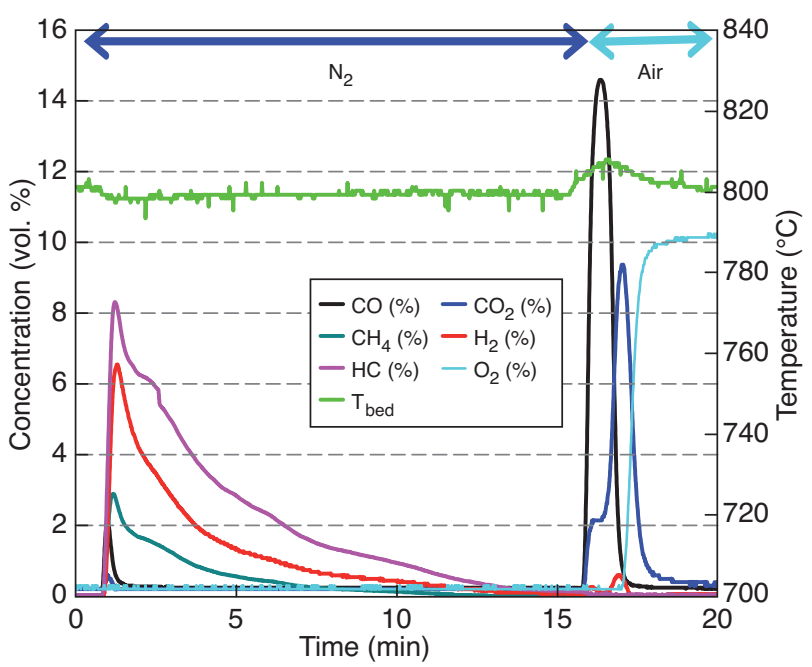

Figure 5

Pyrolysis of dodecane on $\mathrm{SiC}$ at $800^{\circ} \mathrm{C}$. 
A again. The OC particles are fully oxidized, therefore the theoretical amount of oxygen releasable is $12.3 \mathrm{~g}$. In this condition, there is a large excess of oxygen to fully convert the $1 \mathrm{~mL}$ injection of dodecane into $\mathrm{CO}_{2}$ and $\mathrm{H}_{2} \mathrm{O}$.

As shown in Figure 6, after injection of dodecane into the reactor, $\mathrm{CO}_{2}$ and $\mathrm{H}_{2} \mathrm{O}$ are formed and no $\mathrm{CH}_{4}, \mathrm{CO}$ nor $\mathrm{H}_{2}$ can be observed during the carrier reduction time, thus indicating that dodecane conversion is complete. It must be noted that the small peak of hydrogen measured during the increase of $\mathrm{CO}_{2}$ concentration $(1<t<1.5 \mathrm{~min})$ is an artifact: it comes from internal compensation calculation of interference of $\mathrm{CO}_{2}$ on hydrogen by the analyzer.

During reduction, a decrease of the bed temperature can be noticed, due to the endothermic overall reaction in the fuel reactor. After $9 \mathrm{mn}$, air is injected to reoxidize OC particles. However, $\mathrm{CO}$ and $\mathrm{CO}_{2}$ are not detected anymore at the reactor outlet stream. This result indicates that, with the OC particles, there is no significant carbon deposit on oxygen carrier at the end of the reduction step.

\subsection{Series of Dodecane Injections on $\mathrm{NiAl}_{0.44} \mathrm{O}_{1.67}$ at $800^{\circ} \mathrm{C}$ and $900^{\circ} \mathrm{C}$}

Several injections of dodecane are then conducted successively with multiport valve injection system A on the OC particles, respectively at 800 and $900^{\circ} \mathrm{C}$ without intermediate oxidation.

Figure 7 shows flue gas concentration for five consecutive injections of $1 \mathrm{~mL}$ dodecane on a bed of $45 \mathrm{~g}$ of $\mathrm{NiAl}_{0.44} \mathrm{O}_{1.67}$ at $800^{\circ} \mathrm{C}$, respectively conducted at $t=2.0 ; 10.7 ; 21.1 ; 32.7$ and $42.6 \mathrm{~min}$. Clearly, during the two first injections, the

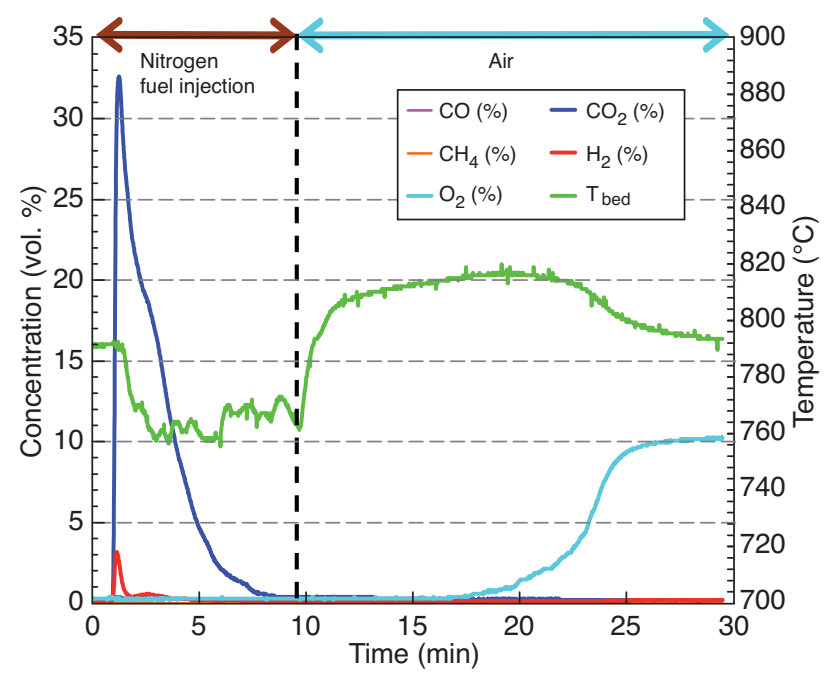

Figure 6

Outlet gas concentration after the injection of dodecane on $\mathrm{NiAl}_{0.44} \mathrm{O}_{1.67}$ at $800^{\circ} \mathrm{C}$.

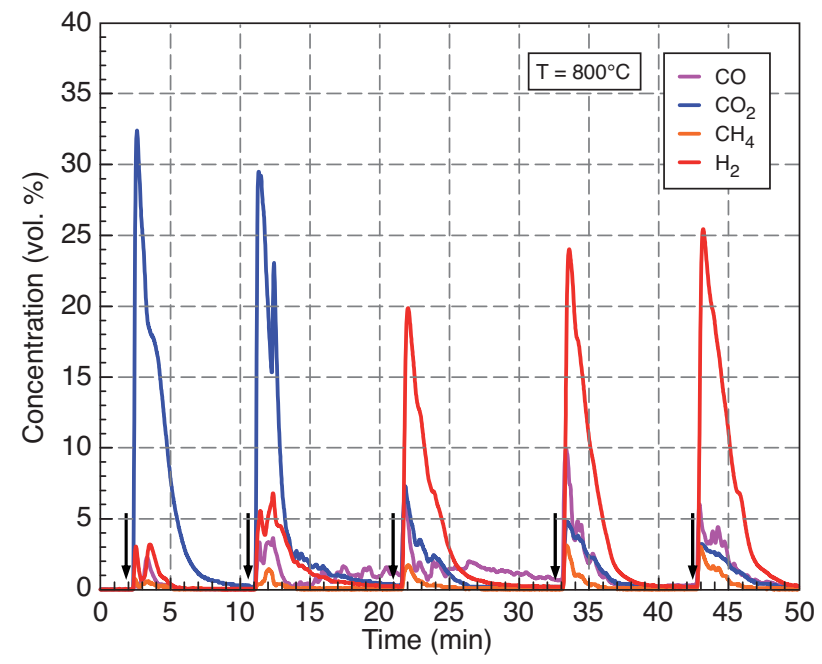

Figure 7

Outlet gas concentration for five consecutive injections of dodecane on $\mathrm{NiAl}_{0.44} \mathrm{O}_{1.67}$ at $800^{\circ} \mathrm{C}$.

conversion of dodecane is complete. This result indicates that, during the second injection time, the amount of available oxygen in the OC particles is still sufficient to convert dodecane into $\mathrm{CO}_{2}$ and steam.

During the third injection, more $\mathrm{CO}$ and $\mathrm{H}_{2}$ and $\mathrm{CH}_{4}$ are detected at the reactor outlet stream. The shift in the reaction is due to the quantity of $\mathrm{O}_{2}$ present in the oxygen carrier during dodecane injection.

A similar experiment is performed with the same OC bed at $900^{\circ} \mathrm{C}$. Figure 8 shows flue gas concentrations for eight consecutive injections of dodecane on $\mathrm{NiAl}_{0.44} \mathrm{O}_{1.67}$ (injections of $1 \mathrm{~mL}$ with multiport valve injection system $\mathrm{A}$ at $t=0.7 ; 10.6 ; 18.7 ; 26.2 ; 28.7 ; 36.0 ; 43.4$ and $54.5 \mathrm{~min}$ ).

The first four injections of dodecane are now converted into $\mathrm{CO}_{2}$ and steam. This suggests that for the same amount of oxygen available from the OC material, the quantity of oxygen transferred at $900^{\circ} \mathrm{C}$ from the fluidized bed to the fuel is higher than it was at $800^{\circ} \mathrm{C}$. This means that oxygen is released easier from the oxygen carrier at $900^{\circ} \mathrm{C}$ than at $800^{\circ} \mathrm{C}$. After 60 minutes, an oxidation step with air is conducted, resulting in an important release of $\mathrm{CO}$, due to the combustion of carbon deposits formed during the last hydrocarbon injections.

\subsection{Feed Effect}

In order to investigate feed effects, the three different fuels described in Table 1 are then injected in the fluidized bed containing $45 \mathrm{~g}$ of $\mathrm{OC}$ particles at $800^{\circ} \mathrm{C}$ in a fully oxydized state. The multiport valve injection system used is now the system B (see Fig. 3). With this new system, $0.85 \mathrm{~mL}$ of 


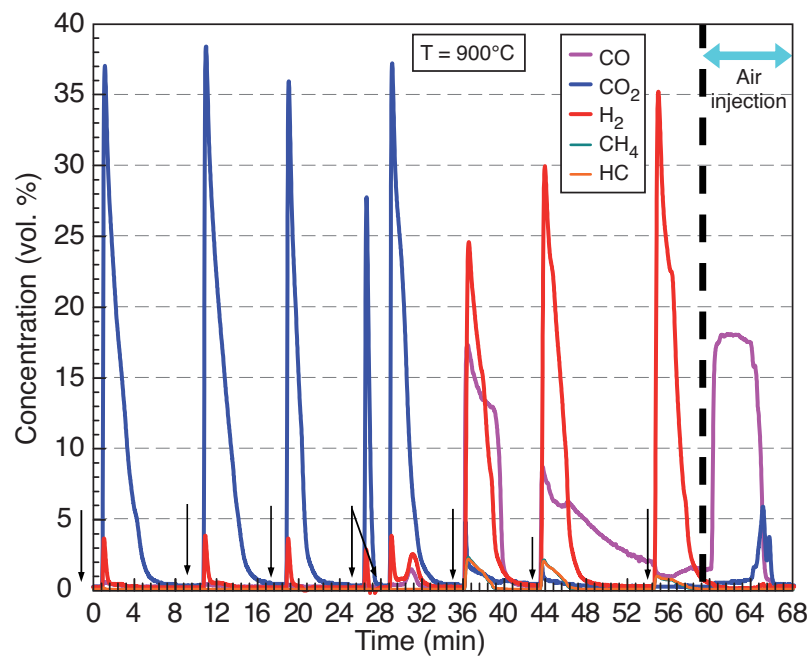

Figure 8

Outlet gas concentration for eight consecutive injections of $1 \mathrm{~mL}$ of dodecane on $\mathrm{NiAl}_{0.44} \mathrm{O}_{1.67}$ at $900^{\circ} \mathrm{C}$. Oxidation for $t>60 \mathrm{~min}$.

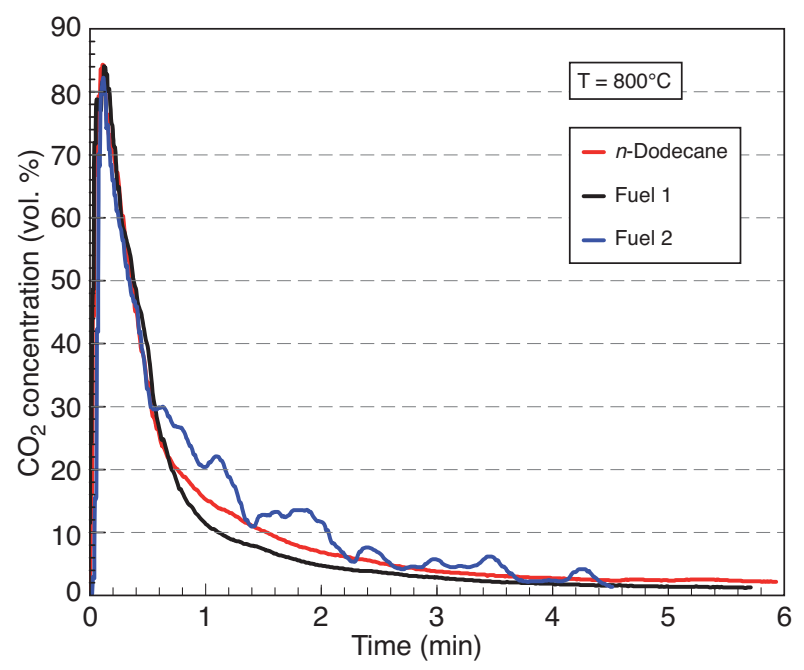

Figure 9

$\mathrm{CO}_{2}$ response to fuel injection (injection time at $t=0$ ).

liquid is injected and the reproducibility of the volumetric quantity of feed injected is greatly improved. The experiments are conducted with a large excess of oxygen available on the $\mathrm{OC}$ particles. Therefore, only $\mathrm{CO}_{2}$ and $\mathrm{H}_{2} \mathrm{O}$ are released.

Figure 9 shows the $\mathrm{CO}_{2}$ flue gas composition as a function of time for the 3 different feeds. In each case, re-oxidation of OC particles is conducted at the end of the experiment, but no $\mathrm{CO}_{2}$ was emitted during this re-oxidation period of time confirming that there was no coke deposit remaining on OC particles at the end of the reduction step, even with the residue feed (Fuel 2).

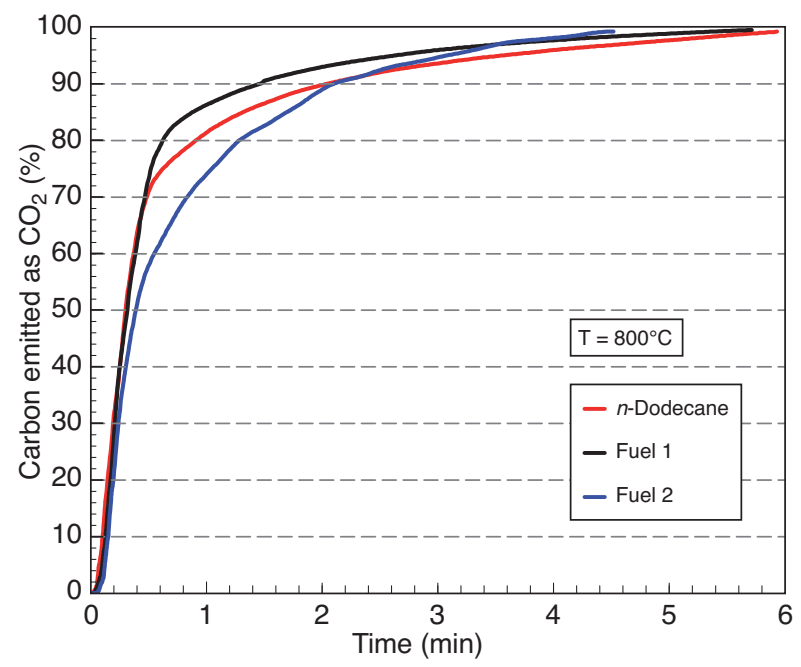

Figure 10

Carbon burning rate as a function of time for the 3 fuels considered.

In Figure 10, the carbon burning rate obtained during those experiments is expressed as a function of time. During the early $30 \mathrm{~s}$ following feed injection, from 40 to $80 \%$ of the carbon from the fuel burns, probably resulting from vaporization and thermal cracking. The remaining carbon burns more slowly. More than 5 minutes are needed to achieved complete combustion during these experiments. Part of the liquid fuel injected may form coke deposits on particles; combustion of this coke takes a longer time due to the limiting gasification step. In any case, it is possible to burn about $90 \%$ of the fuel within 2 minutes.

A lot of work has already been conducted on solid fuel combustion in chemical looping. It is no well-established that solid fuel combustion is enhanced by steam and temperature $[6,7,11]$. Indeed, solid fuel combustion mechanism in CLC is a combination of char gasification and syngas combustion. This work suggests that part of the liquid fuel injected forms coke in the fuel reactor. Therefore, it is expected that steam and temperature may help to reduce the time of combustion of liquid fuel by enhancing gasification of coke deposits.

\section{CONCLUSION}

Experiments presented in this paper extend the feasibility of the Chemical Looping Combustion (CLC) process to liquid fuels. It was shown that dodecane can be fully converted into $\mathrm{CO}_{2}$ and steam using $\mathrm{NiAl}_{0.44} \mathrm{O}_{1.67}$ oxygen carrier. No carbon deposits was detected at the end of the reduction step. This suggests that optimal $\mathrm{CO}_{2}$ capture efficiencies are possible if enough time is provided to burn all hydrocarbons. Light and heavy fuel oils have been tested and in all cases, it was 
possible to burn $90 \%$ of the fuel within 2 minutes despite their very different physical properties. Liquid feedstocks can therefore be also considered for CLC applications, in order to produce energy and $\mathrm{CO}_{2}$ concentrated flue gas ready for to sequestration, or CLR applications (Chemical Looping Reforming) for the production of synthesis gas or for cogeneration of $\mathrm{H}_{2}$ and power.

\section{ACKNOWLEDGMENTS}

The authors acknowledge French National Research Agency for its financial support.

\section{REFERENCES}

1 Anheden M., Svedberg G. (1998) Energ. Convers. Manage. 39, 16-18, 1967-1980.

2 Johansson M., Mattisson T., Lyngfelt A. (2004) Investigation of $\mathrm{Fe}_{2} \mathrm{O}_{3}$ with $\mathrm{MgAl}_{2} \mathrm{O}_{4}$ for chemical-looping combustion, Ind. Eng. Chem. Res. 43, 22, 6978-6987.

3 Cho P., Mattisson T., Lyngfelt A. (2004) Comparison of iron-, nickel-, copper-and manganese-based oxygen carriers for chemicallooping combustion, Fuel 83, 9, 1215-1225.

4 Cao Y., Pan W.-P. (2006) Investigation of chemical looping combustion by solid fuels. 1. Process Analysis, Energ. Fuel. 20, $5,1836-1844$.
5 Cao Y., Casenas B., Pan W.-P. (2006) Investigation of chemical looping combustion by solid fuels. 2. Redox reaction kinetics and product characterization with coal, biomass, and solid waste as solid fuels and $\mathrm{CuO}$ as an oxygen carrier, Energ. Fuel. 20, 5, 1845-1854.

6 Dennis J.S., Scott S.A., Hayhurst A.N. (2006) In situ gasification of coal using steam with chemical looping: a technique for isolating $\mathrm{CO}_{2}$ from burning a solid fuel, J. Energ. Inst. 79, 3, 187-190.

7 Leion H., Mattisson T., Lyngfelt A. (2007) The use of petroleum coke as fuel in chemical-looping combustion, Fuel 86, 12-13, 1947-1958.

8 Scott S.A., Dennis J.S., Hayhurst A.N., Brown T. (2006) In situ gasification of a solid fuel and $\mathrm{CO}_{2}$ separation using chemical looping, AICHE J.52, 9, 3325-3328.

9 Forret A., Hoteit A., Gauthier T. (2009) Chemical Looping Combustion Process applied to liquid fuels, Paper 197c, AIChE Annual Meeting, Nashville, TN.

10 Ishida M., Yamamoto M., Ohba T. (2002) Experimental results of chemical-looping combustion with $\mathrm{NiO} / \mathrm{NiAl}_{2} \mathrm{O}_{4}$ particle circulation at $1200^{\circ} \mathrm{C}$, Energ. Convers. Manage. 43, 1469-1478.

11 Leion H., Mattisson T., Lyngfelt A. (2008) Solid fuels in chemical-looping combustion, Int. J. Greenhouse Gas Control 2 , 180-193.
Final manuscript received in September 2010 Published online in February 2011 